\title{
Greenland ice sheet surface melt extent and trends: 1960-2010
}

\author{
Sebastian H. MERNILD, ${ }^{1}$ Thomas L. MOTE, ${ }^{2}$ Glen E. LISTON ${ }^{3}$ \\ ${ }^{1}$ Climate, Ocean and Sea Ice Modeling Group, Computational Physics and Methods, Los Alamos National Laboratory, \\ Los Alamos, New Mexico 87545, USA \\ E-mail: mernild@lanl.gov \\ ${ }^{2}$ Department of Geography, University of Georgia, Athens, Georgia 30602-2502 USA \\ ${ }^{3}$ Cooperative Institute for Research in the Atmosphere, Colorado State University, Fort Collins, Colorado 80523-1375, USA
}

\begin{abstract}
Observed meteorological data and a high-resolution $(5 \mathrm{~km})$ model were used to simulate Greenland ice sheet surface melt extent and trends before the satellite era (1960-79) and during the satellite era through $2010^{\circ}$. The model output was compared with passive microwave satellite observations of melt extent. For 1960-2010 the average simulated melt extent was $15 \pm 5 \%$. For the period 1960-72, simulated melt extent decreased by an average of $6 \%$, whereas 1973-2010 had an average increase of $13 \%$, with record melt extent in 2010 . The trend in simulated melt extent since 1972 indicated that the melt extent in 2010 averaged twice that in the early 1970s. The maximum and mean melt extents for 2010 were $52 \%\left(\sim 9.5 \times 10^{5} \mathrm{~km}^{2}\right)$ and $28 \%\left(\sim 5.2 \times 10^{5} \mathrm{~km}^{2}\right)$, respectively, due to higher-than-average winter and summer temperatures and lower-than-average winter precipitation. For 2010, the southwest Greenland melt duration was 41-60 days longer than the 1960-2010 average, while the northeast Greenland melt duration was up to 20 days shorter. From 1960 to 1972 the melting period (with a $>10 \%$ melt extent) decreased by an average of 3 days $\mathrm{a}^{-1}$. After 1972, the period increased by an average of 2 days $\mathrm{a}^{-1}$, indicating an extended melting period for the ice sheet of about 70 days: 40 and 30 days in spring and autumn, respectively.
\end{abstract}

\section{INTRODUCTION}

The Greenland ice sheet (GrlS) is the largest reservoir of permanent snow and ice in the Northern Hemisphere $(\sim 7 \mathrm{~m}$ sea-level equivalent) and is highly sensitive to climate changes (e.g. Bamber and others, 2001; Box and others, 2006). Satellite-based observations indicate that in 2007 and 2010 the GrlS had record surface melt extent (Mote, 2007; Tedesco, 2007; Steffen and others, 2008; Tedesco and others, 2011; J.E. Box and others, http://www.arctic.noaa. gov/reportcard/greenland.html) accompanied by unusually high freshwater runoff to the ocean (Mernild and Hasholt, 2009). The extent and duration of surface melting are important for a number of reasons. An altered melting regime can produce substantial differences in surface albedo and energy and moisture balances, especially because wet snow absorbs up to three times more incident solar energy than dry snow (Steffen, 1995). Further, an altered melt regime can influence the ice sheet's surface mass balance (SMB) and runoff and its dynamic and subglacial sliding processes. Mechanisms that link climate, surface hydrology, internal drainage and ice dynamics are poorly understood, and numerical ice-sheet models do not simulate these changes realistically (Nick and others, 2009). This was one of the main reasons why the Intergovernmental Panel on Climate Change (IPCC) Fourth Assessment Report (AR4; Solomon and others, 2007) did not include future predictions for GrlS mass loss contribution related to global sealevel rise. Without a deeper understanding of the surface/ dynamic-sliding interactions and the subsequent hydrodynamic response of ice sheets, neither a best estimate nor an upper bound of future sea-level rise is reliable. Therefore, to quantify and predict GrIS mass loss, including runoff conditions, knowledge about its long-term variations in surface melt extent and trends, including the temporal and spatial distributions, melt intensity and duration, needs to be further developed. This surface meltwater runoff represents about half the annual mass loss from the GrlS (Zwally and Giovinetto, 2001; Rignot and Kanagaratnam, 2006), with iceberg calving generating approximately the other half.

In this paper, we examine the duration, extent and magnitude of the GrlS surface melting from 1960 through 2010. Melting is simulated using SnowModel, a spatially distributed meteorological snow and ice model (Liston and Elder, 2006a,b; Mernild and Liston, 2010) forced with observed meteorological data for the period when reliable forcing data are available. We compare results with observations during the satellite era (1979-2010) and we simulate GrlS melting conditions and trends from 1960 to 2010. Further, we examine whether the 2010 record melt season lies outside the natural melt variability since 1960.

\section{METHODOLOGY AND DATA}

SnowModel (Liston and Elder, 2006a,b; Mernild and others, 2006) is a spatially distributed system for modeling meteorological conditions, snow evolution, snow and ice melting and runoff, given surface meteorological forcing. It simulates surface energy and moisture exchanges, including snow and glacier melt, multi-layer heat- and mass-transfer processes in snow (e.g. snowpack temperature and density evolution) and ice hydrological features such as meltwater routing from the surface through snow, firn and glacial ice. SnowModel routines have been described and tested by, for example, Liston and Elder (2006a,b), Liston and others (2007), Liston and Hiemstra (2008, in press), Mernild and others (2008, 2009, 2010, 2011) and Mernild and Liston (2010) and used successfully in a variety of snow and glacier environments, including the Arctic and Antarctic.

Atmospheric forcing required by SnowModel is provided by MicroMet (Liston and Elder, 2006b), which assimilates and interpolates time series of air temperature, relative humidity, wind speed and direction and precipitation from 


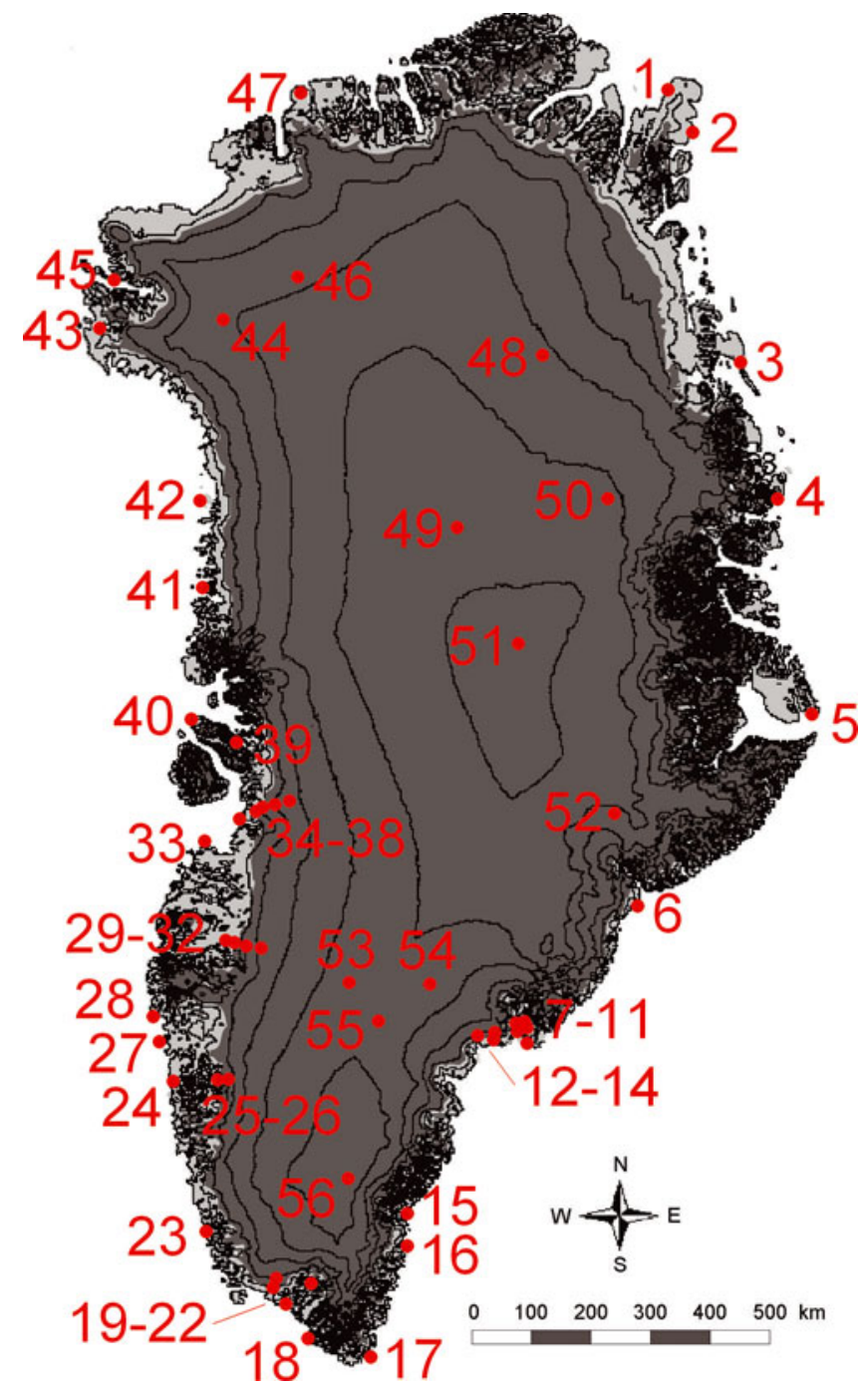

Fig. 1. Greenland simulation domain with topography $(500 \mathrm{~m}$ contour interval) and the location of the coastal and GrIS meteorological tower stations (red dots). Station specifications are provided in Table 1.

surface meteorological stations near or within the simulation domain. MicroMet uses known relationships between meteorological variables and the surrounding landscape (e.g. topography and surface characteristics) to distribute these variables in physically plausible and computationally efficient ways (e.g. Liston and others, 2007; Liston and Hiemstra, 2011). Data are interpolated horizontally to a regular grid using a Barnes objective analysis scheme (Barnes, 1964, 1973; Koch and others, 1983) that applies a Gaussian distance-dependent weighting function. Interpolation weights are determined objectively as a function of data spacing and distribution. At each time-step, air temperature, solar radiation, albedo, outgoing longwave radiation, latent heat flux, sensible heat flux, snowmelt, sublimation, snowmelt runoff, snow depth and snow water equivalent are calculated and made accessible to SnowModel. The SnowModel simulated melt extent (for each daily time-step) was determined by summing the number of gridcells where simulated melt occurred.

Melt simulations were performed on daily time-steps based on: (1) a $5 \mathrm{~km}$ digital elevation model (Bamber and others, 2001) and land cover from the US Geological Survey (USGS) North American Land Cover Characteristics
Database, version 2.0 (http://edcdaac.usgs.gov/glcc/ na_int.html) and (2) observed atmospheric forcing data from 56 meteorological stations located both in coastal areas and on the GrIS (Fig. 1; Table 1). The simulations covered the period September 1959 through December 2010. Userdefined constants used in the simulations are listed by Mernild and others (2009).

Using the increase in microwave emissivity as liquid water forms in previously dry snow (Stiles and Ulaby, 1980), passive microwave satellite sensors were used to determine surface and near-surface melt occurrence for comparison with the SnowModel results. A microwave emission model was used to determine the brightness temperature $\left(T_{\mathrm{B}}\right)$ associated with $1 \%$ volumetric water content each year for locations across the GrlS using the dynamic threshold algorithm given by Mote and Anderson (1995). These modeled $T_{\mathrm{B}}$ values are used as threshold values to distinguish melt from non-melt during the summer of a given year. While Mote and Anderson (1995) used the $37 \mathrm{GHz}$ frequency, this study used the $18 \mathrm{GHz}$ scanning multichannel microwave radiometer (SMMR) and 19.35 GHz Special Sensor Microwave/Imager (SSM/I), following Mote (2007).

The $18 \mathrm{GHz}$ horizontally polarized channel from SMMR (January 1979 to June 1987; http://nsidc.org/data/nsidc0007.html) and 19.35 GHz channel from SSM/I (July 1987 to September 2010; http://nsidc.org/data/nsidc-0001.html) $T_{\mathrm{B}}$ data were extracted from the US National Snow and Ice Data Center polar stereographic daily grids with a nominal $25 \mathrm{~km}$ gridcell increment. The emission model simulated the $T_{\mathrm{B}}$ values associated with melt for each gridcell each year. The melt area was determined by summing the total area covered by cells where the observed $T_{\mathrm{B}}$ exceeded the modeled threshold $T_{\mathrm{B}}$. A comparison of SSM/I melt occurrence with infrared land surface temperatures from the Moderate Resolution Imaging Spectroradiometer (MODIS) in 2006 and 2007 showed that the SSM/I indicated $5-8 \%$ greater melt area; the two products agreed for $93 \%$ of non-cloud-contaminated cells.

\section{RESULTS AND DISCUSSION}

Since 1960, the maximum modeled GrlS melt extent has been in 2010 and the minimum in 1972 (Fig. 2a). For 2010, the maximum melt extent was $\sim 9.5 \times 10^{5} \mathrm{~km}^{2}$, or $52 \%$ of the GrIS surface. This slightly exceeded the previous record of $51 \%$ set in 2007 and was significantly above the 51 year average of $34 \%$. The modeled standard deviation in melt extent from 1960 to 2010 was $9 \%\left((\sim 6.2 \pm 1.7) \times 10^{5} \mathrm{~km}^{2}\right)$. For 1972, a melt extent of $17 \%\left(\sim 3.1 \times 10^{5} \mathrm{~km}^{2}\right)$ was simulated (Fig. 2a). In contrast to the simulated values, the satellite-derived area that underwent melting was more extensive in 2002 than in 2010 (Fig. 3a), indicating surface melt on $80 \%\left(\sim 13.2 \times 10^{5} \mathrm{~km}^{2}\right)$ of the ice sheet. The SSM/I satellite-derived maximum 2002 melt extent is different from the results based on cross-polarized gradient ratio (XPGR) algorithms (Abdalati and Steffen, 1997; Steffen and others, 2008 and updated), where 2010 was a record year, close to values from 2007 (personal communication from K. Steffen, 2010). A possible reason for the extremely high SSM/I satellite-observed 2002 melt extent might be the greater sensitivity of the dynamic threshold algorithm to melt onset compared with the XPGR algorithm (Anderson and others, 1996). Furthermore, while the dynamic threshold algorithm 
Table 1. Meteorological input data for the GrlS melt extent simulations. Stations were operated and data were provided by the Danish Meteorological Institute (DMI)), University of Colorado at Boulder (CU), Geological Survey of Denmark and Greenland (GEUS), University of Copenhagen (UC) and University of Utrecht (UU). Parameters are Ta: air temperature; Rh: relative humidity; Ws: wind speed; Wd: wind direction; and P: precipitation. For station locations see Figure 1

\begin{tabular}{lllll}
\hline Station & Station name & Grid & Altitude & Data period
\end{tabular}

No. $m$ a.s.I.

\begin{tabular}{|c|c|c|c|c|c|c|}
\hline 1 & Station Nord & $81^{\circ} 36^{\prime} 00^{\prime \prime} \mathrm{N}, 16^{\circ} 39^{\prime} 00^{\prime \prime} \mathrm{W}$ & 36 & 1 Sept 1961 to 9 Jul 2007 & Ta, Rh, Ws, Wd, P & DMI \\
\hline 2 & Henrik Krøyer Holme & $80^{\circ} 39^{\prime} 00^{\prime \prime} \mathrm{N}, 13^{\circ} 43^{\prime} 00^{\prime \prime} \mathrm{W}$ & 10 & 1 Sept 1985 to current & Ta, Rh, Ws, Wd & DMI \\
\hline 3 & Danmarkshavn & $76^{\circ} 46^{\prime} 00^{\prime \prime} \mathrm{N}, 18^{\circ} 40^{\prime} 00^{\prime \prime} \mathrm{W}$ & 11 & 1 Sept 1959 to current & Ta, Rh, Ws,Wd, P & DMI \\
\hline 5 & Ittoqqortoormiit & $70^{\circ} 29^{\prime} 00^{\prime \prime} \mathrm{N}, 21^{\circ} 57^{\prime} 00^{\prime \prime} \mathrm{W}$ & 66 & 1 Nov 1980 to current & Ta, Rh, Ws, Wd, P & DMI \\
\hline 6 & Aputiteeq & $67^{\circ} 47^{\prime} 00^{\prime \prime} \mathrm{N}, 32^{\circ} 18^{\prime} 00^{\prime \prime} \mathrm{W}$ & 13 & 1 Sept 1959 to 9 Feb 1987 & Ta, Rh, Ws, Wd, P & DMI \\
\hline 7 & Tasiilaq & $65^{\circ} 36^{\prime} 00^{\prime \prime} \mathrm{N}, 37^{\circ} 38^{\prime} 00^{\prime \prime} \mathrm{W}$ & 44 & 1 Sept 1959 to current & $\mathrm{Ta}, \mathrm{Rh}, \mathrm{Ws}, \mathrm{Wd}, \mathrm{P}$ & DMI \\
\hline 9 & Sermilik, Station Coast_U & $65^{\circ} 40^{\prime} 20^{\prime \prime} \mathrm{N}, 37^{\circ} 54^{\prime} 10^{\prime \prime} \mathrm{W}$ & 190 & 1 Aug 2009 to current & Ta, Rh, Ws, Wd & UC, IGG \\
\hline 10 & Sermilik, Station Nunatak & $65^{\circ} 42^{\prime} 00^{\prime \prime} \mathrm{N}, 37^{\circ} 49^{\prime} 00^{\prime \prime} \mathrm{W}$ & 515 & 1 Jun 1997 to current & $\mathrm{Ta}, \mathrm{Rh}, \mathrm{Ws}, \mathrm{Wd}$ & UC, IGG \\
\hline 11 & MIT & $65^{\circ} 41^{\prime} 33^{\prime \prime} \mathrm{N}, 37^{\circ} 49^{\prime} 34^{\prime \prime} \mathrm{W}$ & 460 & 3 May 2009 to 29 Oct 2010 & Ta, Rh, Ws & GEUS \\
\hline 12 & TAS_L & $65^{\circ} 38^{\prime} 00^{\prime \prime} \mathrm{N}, 38^{\circ} 54^{\prime} 00^{\prime \prime} \mathrm{W}$ & 270 & 26 Jun 2006 to 12 Feb 2010 & Ta, Rh,Ws, Wd & GEUS \\
\hline 13 & TAS_U & $65^{\circ} 42^{\prime} 00^{\prime \prime} \mathrm{N}, 38^{\circ} 52^{\prime} 00^{\prime \prime} \mathrm{W}$ & 580 & 16 Apr 2004 to 26 Oct 2010 & Ta, Rh, Ws, Wd & GEUS \\
\hline 14 & KULU & $65^{\circ} 45^{\prime} 00^{\prime \prime} \mathrm{N}, 38^{\circ} 36^{\prime} 00^{\prime \prime} \mathrm{W}$ & 880 & 20 Jun 1999 to 13 Sept 2000 & $\mathrm{Ta}, \mathrm{Rh}, \mathrm{Ws}, \mathrm{Wd}$ & $\mathrm{CU}, \mathrm{CIRES}(\mathrm{GC}-\mathrm{NET})^{\dagger}$ \\
\hline 15 & Timmiarmiut & $62^{\circ} 32^{\prime} 00^{\prime \prime} \mathrm{N}, 42^{\circ} 08^{\prime} 00^{\prime \prime} \mathrm{W}$ & 10 & 1 Sept 1959 to 30 Jun 1979 & Ta, Rh, Ws,Wd, P & DMI \\
\hline 17 & Ikerasassuaq & $60^{\circ} 03^{\prime} 00^{\prime \prime} \mathrm{N}, 43^{\circ} 10^{\prime} 00^{\prime \prime} \mathrm{W}$ & 88 & 1 Sept 1959 to current & Ta, Rh, Ws, Wd, P & DMI \\
\hline 18 & Nanortalik & $60^{\circ} 08^{\prime} 00^{\prime \prime} \mathrm{N}, 45^{\circ} 13^{\prime} 00^{\prime \prime} \mathrm{W}$ & 21 & 2 Jan 1961 to current & $\mathrm{Ta}, \mathrm{Rh}, \mathrm{Ws}, \mathrm{Wd}, \mathrm{P}$ & DMI \\
\hline 19 & Qaqortoq & $60^{\circ} 43^{\prime} 00^{\prime \prime} \mathrm{N}, 46^{\circ} 03^{\prime} 00^{\prime \prime} \mathrm{W}$ & 32 & 1 Jan 1961 to current & Ta, Rh, Ws, Wd, P & DMI \\
\hline 20 & Mitt. Narsarsuaq & $61^{\circ} 10^{\prime} 00^{\prime \prime} \mathrm{N}, 45^{\circ} 25^{\prime} 00^{\prime \prime} \mathrm{W}$ & 27 & 1 Jan 1961 to current & Ta, Rh, Ws,Wd, P & DMI \\
\hline 21 & QAS_L & $61^{\circ} 01^{\prime} 54^{\prime \prime} \mathrm{N}, 45^{\circ} 50^{\prime} 54^{\prime \prime} \mathrm{W}$ & 310 & 9 May 2003 to 31 Jul 2010 & Ta, Rh, Ws, Wd & GEUS \\
\hline 22 & QAS_U & $61^{\circ} 10^{\prime} 42^{\prime \prime} \mathrm{N}, 46^{\circ} 49^{\prime} 00^{\prime \prime} \mathrm{W}$ & 890 & 7 Aug 2008 to 19 Jul 2010 & $\mathrm{Ta}, \mathrm{Rh}, \mathrm{Ws}, \mathrm{Wd}$ & GEUS \\
\hline 23 & Paamiut & $62^{\circ} 00^{\prime} 00^{\prime \prime} \mathrm{N}, 49^{\circ} 40^{\prime} 00^{\prime \prime} \mathrm{W}$ & 13 & 1 Sept 1959 to current & Ta, Rh, Ws,Wd, P & DMI \\
\hline 24 & Nuuk & $64^{\circ} 10^{\prime} 00^{\prime \prime} \mathrm{N}, 51^{\circ} 45^{\prime} 00^{\prime \prime} \mathrm{W}$ & 80 & 1 Sept 1959 to current & Ta, Rh, Ws, Wd, P & DMI \\
\hline 25 & NUK_L & $64^{\circ} 28^{\prime} 54^{\prime \prime} \mathrm{N}, 49^{\circ} 31^{\prime} 42^{\prime \prime} \mathrm{W}$ & 560 & 20 Aug 2007 to 30 Oct 2010 & Ta, Rh, Ws, Wd & GEUS \\
\hline 26 & NUK_U & $64^{\circ} 29^{\prime} 54^{\prime \prime} \mathrm{N}, 49^{\circ} 15^{\prime} 54^{\prime \prime} \mathrm{W}$ & 1140 & 20 Aug 2007 to 26 Oct 2010 & Ta, Rh, Ws, Wd & GEUS \\
\hline 27 & Sioralik & $65^{\circ} 01^{\prime} 00^{\prime \prime} \mathrm{N}, 52^{\circ} 33^{\prime} 00^{\prime \prime} \mathrm{W}$ & 14 & 16 Jun 1983 to current & Ta, Rh, Ws, Wd & DMI \\
\hline 28 & Mitt. Maniitsoq & $65^{\circ} 25^{\prime} 00^{\prime \prime} \mathrm{N}, 52^{\circ} 56^{\prime} 00^{\prime \prime} \mathrm{W}$ & 28 & 6 Dec 2000 to current & $\mathrm{Ta}, \mathrm{Rh}, \mathrm{Ws}, \mathrm{Wd}$ & DMI \\
\hline 29 & Kangerlussuaq & $67^{\circ} 01^{\prime} 00^{\prime \prime} \mathrm{N}, 50^{\circ} 42^{\prime} 00^{\prime \prime} \mathrm{W}$ & 50 & 1 May 1973 to current & Ta, Rh, Ws, Wd, P & DMI \\
\hline 30 & Station S5 & $67^{\circ} 06^{\prime} 00^{\prime \prime} \mathrm{N}, 50^{\circ} 07^{\prime} 00^{\prime \prime} \mathrm{W}$ & 490 & 1 Sept 2006 to 18 Aug 2010 & Ta, Rh, Ws & UU \\
\hline 31 & Station S6 & $67^{\circ} 05^{\prime} 00^{\prime \prime} \mathrm{N}, 49^{\circ} 23^{\prime} 00^{\prime \prime} \mathrm{W}$ & 1020 & 1 Sept 2006 to 14 Jul 2010 & Ta, Rh, Ws & UU \\
\hline 33 & Aasiaat & $68^{\circ} 42^{\prime} 00^{\prime \prime} \mathrm{N}, 52^{\circ} 45^{\prime} 00^{\prime \prime} \mathrm{W}$ & 43 & 1 Jan 1959 to current & $\mathrm{Ta}, \mathrm{Rh}, \mathrm{Ws}, \mathrm{Wd}, \mathrm{P}$ & DMI \\
\hline 34 & Mitt. Ilulissat & $69^{\circ} 14^{\prime} 00^{\prime \prime} \mathrm{N}, 51^{\circ} 04^{\prime} 00^{\prime \prime} \mathrm{W}$ & 29 & 15 Aug 1991 to current & $\mathrm{Ta}, \mathrm{Rh}, \mathrm{Ws}, \mathrm{Wd}$ & DMI \\
\hline 35 & JAR1 & $69^{\circ} 29^{\prime} 51^{\prime \prime} \mathrm{N}, 49^{\circ} 41^{\prime} 16^{\prime \prime} \mathrm{W}$ & 962 & 20 Jun 1996 to 12 May 2010 & Ta, Rh, Ws, Wd & CU, CIRES (GC-NET) \\
\hline 36 & JAR2 & $69^{\circ} 25^{\prime} 09^{\prime \prime} \mathrm{N}, 50^{\circ} 03^{\prime} 55^{\prime \prime} \mathrm{W}$ & 542 & 2 Jun 1999 to 14 May 2010 & Ta, Rh, Ws, Wd & CU, CIRES (GC-NET) \\
\hline 37 & JAR3 & $69^{\circ} 23^{\prime} 40^{\prime \prime} \mathrm{N}, 50^{\circ} 18^{\prime} 36^{\prime \prime} \mathrm{W}$ & 283 & 1 Jan 2001 to 24 May 2004 & Ta, Rh, Ws, Wd & CU, CIRES (GC-NET) \\
\hline 38 & Swiss Camp & $69^{\circ} 34^{\prime} 03^{\prime \prime} \mathrm{N}, 49^{\circ} 19^{\prime} 17^{\prime \prime} \mathrm{W}$ & 1.140 & 1 Jan 1995 to 10 May 2010 & Ta, Rh, Ws, Wd & CU, CIRES (GC-NET) \\
\hline 39 & Uummannaq & $70^{\circ} 40^{\prime} 00^{\prime \prime} \mathrm{N}, 52^{\circ} 07^{\prime} 00^{\prime \prime} \mathrm{W}$ & 39 & 1 Jan 1961 to 30 Jun 2006 & $\mathrm{Ta}, \mathrm{Rh}, \mathrm{Ws}, \mathrm{Wd}, \mathrm{P}$ & DMI \\
\hline 40 & Nuussuaq & $70^{\circ} 41^{\prime} 00^{\prime \prime} \mathrm{N}, 54^{\circ} 37^{\prime} 00^{\prime \prime} \mathrm{W}$ & 27 & 1 Jan 1961 to current & $\mathrm{Ta}, \mathrm{Rh}, \mathrm{Ws}, \mathrm{Wd}, \mathrm{P}$ & DMI \\
\hline 41 & Upernavik & $72^{\circ} 47^{\prime} 00^{\prime \prime} \mathrm{N}, 56^{\circ} 10^{\prime} 00^{\prime \prime} \mathrm{W}$ & 120 & 25 Oct 2000 to current & Ta, Rh, Ws, Wd & DMI \\
\hline 42 & Kitsissorsuit & $74^{\circ} 02^{\prime} 00^{\prime \prime} \mathrm{N}, 57^{\circ} 49^{\prime} 00^{\prime \prime} \mathrm{W}$ & 40 & 10 Sept 1981 to current & Ta, Rh, Ws, Wd & DMI \\
\hline 43 & Pituffik & $76^{\circ} 32^{\prime} 00^{\prime \prime} \mathrm{N}, 68^{\circ} 45^{\prime} 00^{\prime \prime} \mathrm{W}$ & 77 & 1 Jan 1974 to 27 Nov 2006 & $\mathrm{Ta}, \mathrm{Rh}, \mathrm{Ws}, \mathrm{Wd}, \mathrm{P}$ & DMI \\
\hline 44 & GITS & $77^{\circ} 08^{\prime} 16^{\prime \prime} \mathrm{N}, 61^{\circ} 02^{\prime} 24^{\prime \prime} \mathrm{W}$ & 1869 & 7 Jun 1995 to 2 May 2007 & Ta, Rh, Ws, Wd & CU, CIRES (GC-NET) \\
\hline 45 & Qaanaaq & $77^{\circ} 28^{\prime} 00^{\prime \prime} \mathrm{N}, 69^{\circ} 13^{\prime} 00^{\prime \prime} \mathrm{W}$ & 16 & 10 Aug 1995 to 13 Oct 2004 & Ta, Rh, Ws, Wd & DMI \\
\hline 46 & Humboldt & $78^{\circ} 31^{\prime} 36^{\prime \prime} \mathrm{N}, 56^{\circ} 49^{\prime} 50^{\prime \prime} \mathrm{W}$ & 1995 & 22 Jun 1995 to 30 Apr 2008 & $\mathrm{Ta}, \mathrm{Rh}, \mathrm{Ws}, \mathrm{Wd}$ & CU, CIRES (GC-NET) \\
\hline 47 & Hall Land & $81^{\circ} 41^{\prime} 00^{\prime \prime} \mathrm{N}, 59^{\circ} 57^{\prime} 00^{\prime \prime} \mathrm{W}$ & 105 & 30 Aug 1982 to 6 Sept 2007 & $\mathrm{Ta}, \mathrm{Rh}, \mathrm{Ws}, \mathrm{Wd}$ & DMI \\
\hline 48 & Tunu-N & $78^{\circ} 00^{\prime} 59^{\prime \prime} \mathrm{N}, 33^{\circ} 59^{\prime} 00^{\prime \prime} \mathrm{W}$ & 2052 & 17 May 1995 to 1 May 2008 & Ta, Rh, Ws, Wd & CU, CIRES (GC-NET) \\
\hline 49 & NorthGRIP & $75^{\circ} 05^{\prime} 59^{\prime \prime} \mathrm{N}, 42^{\circ} 19^{\prime} 57^{\prime \prime} \mathrm{W}$ & 2950 & 9 Jul 1997 to 8 May 2010 & Ta, Rh, Ws, Wd & CU, CIRES (GC-NET) \\
\hline 50 & NASA-E & $75^{\circ} 00^{\prime} 02^{\prime \prime} \mathrm{N}, 29^{\circ} 59^{\prime} 50^{\prime \prime} \mathrm{W}$ & 2614 & 3 May 1997 to 2 May 2008 & Ta, Rh, Ws, Wd & CU, CIRES (GC-NET) \\
\hline 51 & Summit & $72^{\circ} 34^{\prime} 47^{\prime \prime} \mathrm{N}, 38^{\circ} 30^{\prime} 18^{\prime \prime} \mathrm{W}$ & 3208 & 14 May 1995 to 16 Aug 2010 & Ta, Rh, Ws, Wd & CU, CIRES (GC-NET) \\
\hline 52 & KAR & $69^{\circ} 41^{\prime} 58^{\prime \prime} \mathrm{N}, 33^{\circ} 00^{\prime} 21^{\prime \prime} \mathrm{W}$ & 2579 & 18 May 1998 to 7 Jun 2005 & Ta, Rh, Ws, Wd & CU, CIRES (GC-NET) \\
\hline 53 & DYE-2 & $66^{\circ} 28^{\prime} 48^{\prime \prime} \mathrm{N}, 46^{\circ} 16^{\prime} 44^{\prime \prime} \mathrm{W}$ & 2165 & 25 May 1995 to 30 Apr 2010 & Ta, Rh, Ws, Wd & CU, CIRES (GC-NET) \\
\hline 54 & NASA-SE & $66^{\circ} 28^{\prime} 45^{\prime \prime} \mathrm{N}, 42^{\circ} 29^{\prime} 56^{\prime \prime} \mathrm{W}$ & 2393 & 24 Apr 1998 to 29 Apr 2010 & Ta, Rh, Ws, Wd & CU, CIRES (GC-NET) \\
\hline 55 & Saddle & $65^{\circ} 59^{\prime} 58^{\prime \prime} \mathrm{N}, 44^{\circ} 30^{\prime} 03^{\prime \prime} \mathrm{W}$ & 2456 & 20 Apr 1997 to 26 Apr 2009 & Ta, Rh, Ws,Wd & CU, CIRES (GC-NET) \\
\hline 56 & South Dome & $63^{\circ} 08^{\prime} 56^{\prime \prime} \mathrm{N}, 44^{\circ} 49^{\prime} 02^{\prime \prime} \mathrm{W}$ & 2901 & 23 Apr 1997 to 30 Jun 2008 & $\mathrm{Ta}, \mathrm{Rh}, \mathrm{Ws}, \mathrm{Wd}$ & CU, CIRES (GC-NET) \\
\hline
\end{tabular}

*Institute for Geography and Geology, University of Copenhagen.

${ }^{\dagger}$ Cooperative Institute for Research in Environmental Sciences (Greenland Climate Network). 

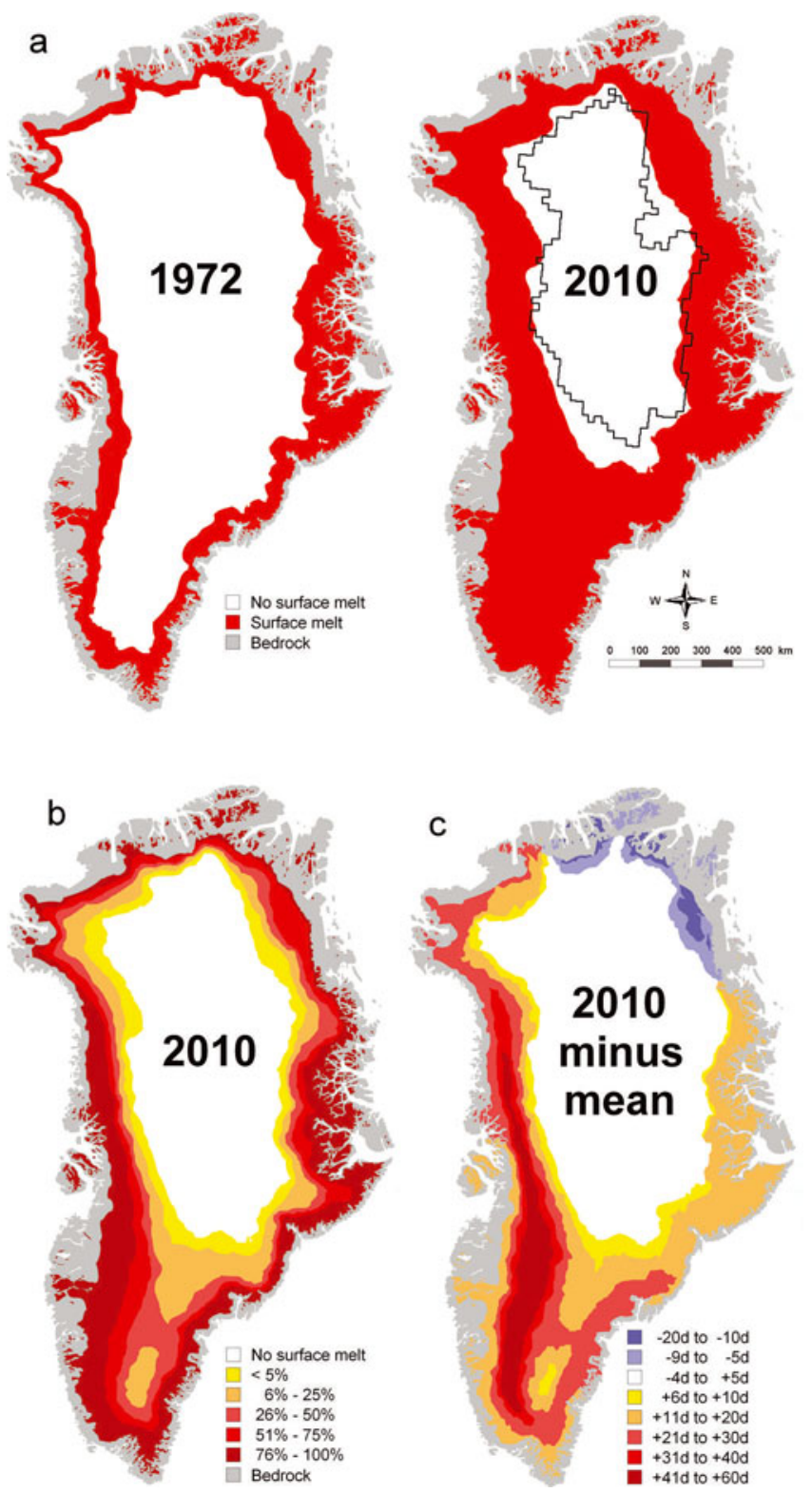

Fig. 2. (a) Maximum simulated GrlS surface melt extent for 1972 (the year with minimum melt extent within the time series 19602010) and 2010 (the year with maximum melt extent). The satellitederived boundary between melting and melt-free areas is shown for 2010 (bold black curve). (b) Simulated 2010 melt frequency in percentage of total melt days. (c) The difference between 2010 simulated melt duration and the 1960-2010 mean, in days.

used here showed a slightly greater total area underwent melt in 2002, it also showed that 2007 and 2010 had more frequent melt and longer melt seasons than 2002. For 2010, simulated surface melting occurred at elevations as high as 3000 ma.s.I., whereas for 1972 surface melting occurred only up to $2400 \mathrm{~m}$ a.s.l. Simulated melt extent was distributed largely as expected, with no melting at higher elevations in the interior of the GrIS (Fig. 2a), while marginal regions had surface melt $76-100 \%$ of the time during the summer (May to September), with melting most pronounced in southwest Greenland (Fig. 2b).

In Figure 2a, the maximum simulated 2010 melt extent is compared with satellite-derived melt extent. The simulated boundary between melting and melt-free areas is highly consistent with the satellite-derived boundary, with an average discrepancy of $40 \pm 35 \mathrm{~km}$. The discrepancy was larger (up to $\sim 160 \mathrm{~km}$ ) in the northeast and northwest and in the southern part of the interior. Differences between satellite-derived and simulated results were most pronounced where the distance between meteorological stations was largest. However, the general correspondence between simulations and observations supports the use of SnowModel for analyzing melting conditions before the satellite era (1960-79) when reliable atmospheric forcing data are available.

The difference between the 2010 melt duration and the 1960-2010 mean is illustrated in Figure 2c. The melt duration in 2010 was 41-60 days longer than the 19602010 average, with the largest differences occurring at the southwestern and western margins of the ice sheet at elevations up to $\sim 2000 \mathrm{~m}$ a.s.l. According to meteorological observations and US National Centers for Environmental Prediction/US National Center for Atmospheric Research (NCEP/NCAR) reanalysis data, this melting was consistent with anomalous warm airflow from the south during spring and summer, and record high winter air temperature leading to warm pre-melt conditions (Box and others, http:// www.arctic.noaa.gov/reportcard/greenland.html), along with somewhat lower-than-average winter precipitation. Low winter snowfall led to earlier exposure of glacier ice and of the previous year's summer snow surface; these surfaces have a lower albedo than fresh snow, promoting greater solar absorption and increased melting (Oke, 1987; Douville and others, 1995). For example, at Nuuk $\left(64.2^{\circ} \mathrm{N}\right.$ along Greenland's west coast) the 2009/10 winter, spring and summer were the warmest since record-keeping began in 1873. Similarly, Aasiaat $\left(69.0^{\circ} \mathrm{N}\right.$ along Greenland's west coast) had its warmest year since record-keeping began in 1951 (Box and others, http://www.arctic.noaa.gov/reportcard/greenland.html), and Greenland's winter precipitation in 2009/10 was $\sim 35 \%$ below the 1960-2010 average.

Melt durations in low-elevation areas along the southeast and east margins were up to 30 and 20 days longer than average, respectively. Along the northeastern portion of the ice-sheet margin, where winter temperatures were lower than average, the 2010 melt duration was up to 20 days less than the long-term average, probably due to regional variability in the atmospheric circulation and a late start to the melt season because of a greater cold content of the snowpack. As a whole, the $2010 \mathrm{GrlS}$ melt duration was $14 \pm 16$ days longer than the 1960-2010 average, with a longer than average melt season on $89 \%$ of the GrlS. Because our model simulations were performed at relatively high resolution, the spatial heterogeneity in duration was greater than that of coarser-resolution satellite observations as described, for example, by Mote (2007 and updated) and Box and others (http://www.arctic.noaa.gov/reportcard/ greenland.html). Overall, however, the simulated melt duration was consistent with the pattern identified by Box and others (http://www.arctic.noaa.gov/reportcard/greenland.html, fig. GL3) for 1979-2010 (Fig. 2c).

For 1960-2010, time series of simulated maximum melt extent showed interannual variability superimposed on a period from 1960 to 1972 that can be approximated by a linear decreasing trend $(p<0.10$, where $p$ is level of significance $)$ of $7 \%\left(\sim 1.2 \times 10^{5} \mathrm{~km}^{2}\right)$ of the total area of the GrIS (Fig. 3a). After 1972, the maximum melt extent increased significantly $(p<0.01)$ by $22 \%\left(\sim 3.7 \times 10^{5} \mathrm{~km}^{2}\right)$ of the GrlS area, consistent overall with the increase in GrIS 

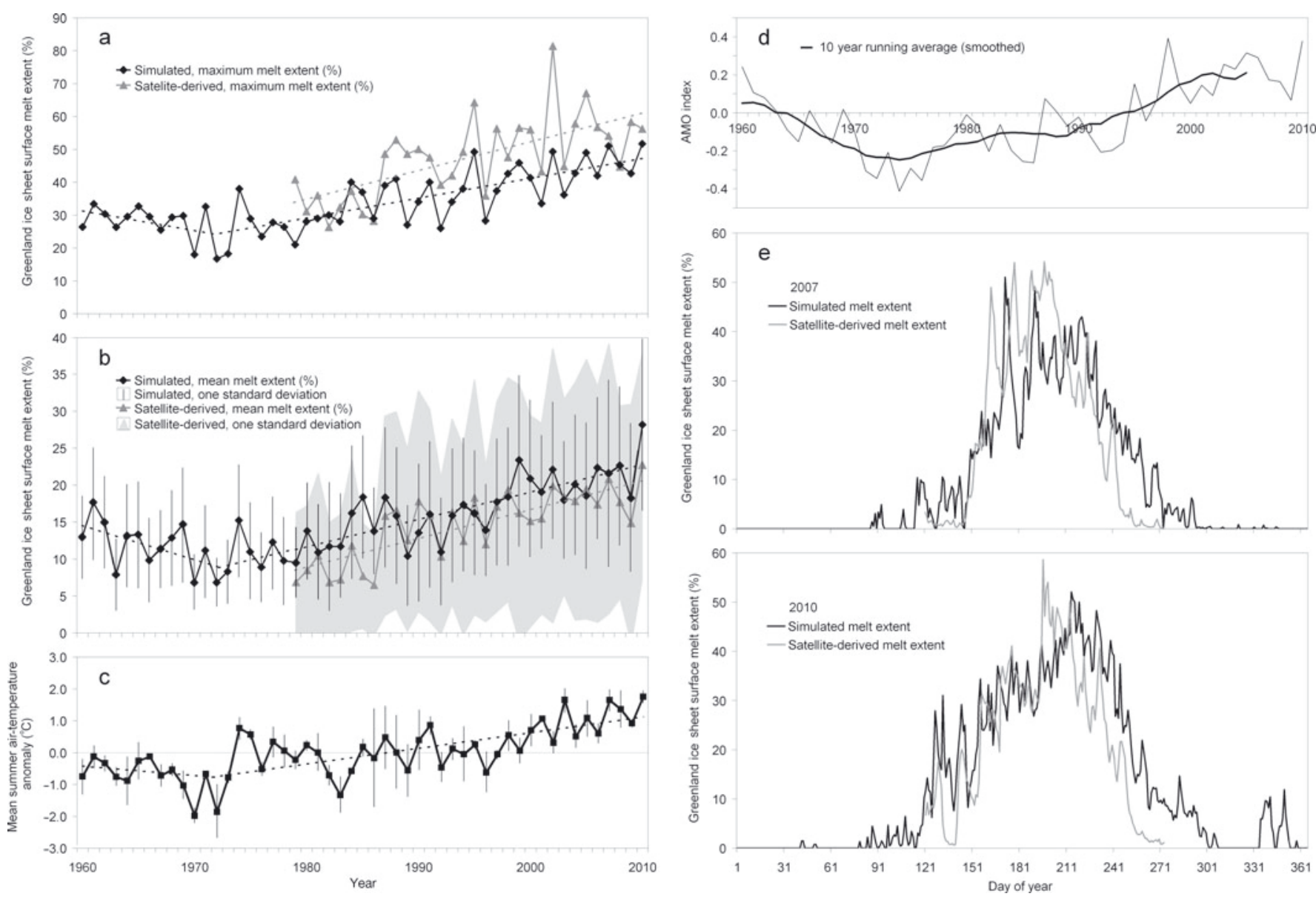

Fig. 3. (a) Time series of simulated annual maximum GrlS melt extent (1960-2010) and satellite-derived maximum melt extent (1979-2010). (b) Time series of seasonal mean (May through September) simulated (1960-2010) and satellite-derived (1979-2010) GrlS melt extent and standard deviation. (c) Mean Greenland summer air temperature anomaly with standard deviation (1960-2010). (d) Unsmoothed and smoothed Atlantic multi-decadal oscillation index (http://www.esrl.noaa.gov/psd/data/timeseries/AMO/). (e) Simulated and satellite-derived seasonal melt extent in 2007 and 2010

maximum melt extent estimated by Fettweis and others (2011). Likewise, the satellite-derived maximum melt extent (Fig. 3a) increased significantly $(p<0.01)$ by $27 \% \quad(\sim 4.4$ $\times 10^{5} \mathrm{~km}^{2}$ ) from 1979 to 2010 and is in general agreement with the SnowModel results. The correlation between satellite-derived maximum melt extent and the simulated maximum melt extent is $r^{2}=0.56$ (based on linear regression; where $r^{2}$ is the explained variance), indicating a statistical significance at the $95 \%$ level $(p<0.05$; i.e. there is $<5 \%$ probability that such a correlation between the two time series can be produced by chance) and an rmse of 55\%.

The maximum melt extents shown in Figures 2 and $3 a$ are snapshots of surface melt. For studying seasonal climate impacts on SMB and runoff, it can be more appropriate to study the mean of integrated seasonal melt extent, as shown in Figure $3 \mathrm{~b}$. The simulated mean annual melt extent was $15 \pm 5 \%$ (1960-2010), and the simulated mean melt extent of $17 \pm 4 \%\left((\sim 3.0 \pm 0.7) \times 10^{5} \mathrm{~km}^{2}\right)(1979-2010)$ is significant (97.5\% quantile) compared with the satellite-derived melt extent of $15 \pm 5 \%\left((\sim 2.6 \pm 0.8) \times 10^{5} \mathrm{~km}^{2}\right)$ and within one standard deviation of the observed values (Fig. 3b). For the mean modeled melt extent, a significant $(p<0.01)$ decreasing trend amounting to $6 \%$ of the GrIS area $\left(\sim 1.1 \times 10^{5} \mathrm{~km}^{2}\right)$ occurred from 1960 to 1972. After 1972, the GrlS exhibited a reversal of this trend, with a significantly increasing trend in melt extent of $13 \%$ of the GrIS area $\left(2.4 \times 10^{5} \mathrm{~km}^{2}\right)$ found in the simulations $(1972-2010 ; p<0.01)$ and a slightly smaller increase of $12 \%\left(\sim 2.0 \times 10^{5} \mathrm{~km}^{2}\right)$ derived from the satellite observations (1979-2010; $p<0.01)$, meaning that larger areas of dry snow were turned into percolation facies. The simulated melt extent since 1972 indicates that the melt extent in 2010 averaged more than twice that of the early 1970s. Many studies have demonstrated that the GrIS melt extent is greater than in the past (Mote, 2007; Tedesco, 2007; Hanna and others, 2008; Steffen and others, 2008; Mernild and others, 2009, 2010; Fettweis and others, 2011; Tedesco and others, 2011; Box and others, http://www.arctic.noaa. gov/reportcard/greenland.html) and SnowModel results offer additional confirmation of these trends at a higher resolution. The increase in melt extent is associated with an observed rise in Greenland mean summer air temperature of $2.3^{\circ} \mathrm{C}$ for 1972-2010 (Fig. 3c) and with a rise in coastal Greenland summer temperatures of $1.7^{\circ} \mathrm{C}$ based on available long-term weather-station data for 1991-2006 (Hanna and others, 2008). Furthermore, the overall trends in mean melt extent (Fig. 3b) seem to correlate with the smoothed trends of the Atlantic multi-decadal oscillation (AMO) index (Fig. 3d). From 1960 to the beginning of the 1970s the smoothed AMO index decreased on average and thereafter it increased towards 2010, analogous with the trends in melt extent for the GrIS. Chylek and others (2010) showed that the Arctic detrended temperatures were highly correlated with $\mathrm{AMO}$, 

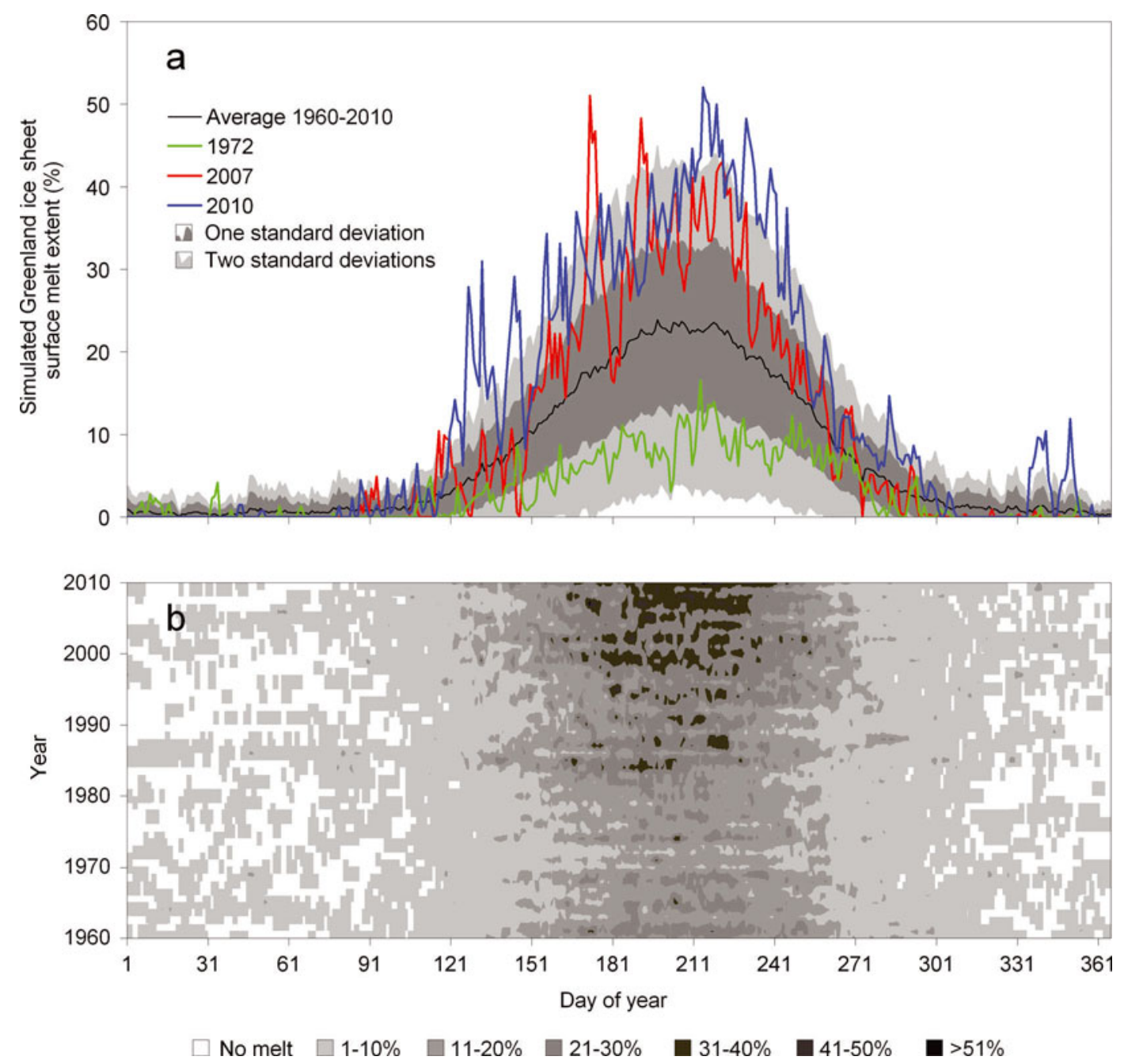

Fig. 4. (a) Time series of maximum daily simulated GrlS melt extent from 1972, 2007, 2010 and average 1960-2010, including standard deviations. (b) Maximum daily simulated GrIS melt extent from January through December for 1960-2010.

suggesting the Atlantic Ocean as a possible source of Arctic climate variability.

The impacts from major episodic volcanic eruptions (e.g. Agung, Indonesia (1963), El Chichón, Mexico (1982) and Pinatubo, Philippines (1991)) do not appear to have a significant impact on melt extent variations (Fig. 3b), even though, as stated by Hanna and others (2005), global dust veils generated by volcanic activity might cool the polar regions and suppress ice-sheet melt.

According to simulations, the GrlS had the lowest mean melt extent of $7 \%\left(\sim 1.2 \times 10^{5} \mathrm{~km}^{2}\right)$ in 1972 and the highest mean melt extent in 2010; the satellite observations also affirm that 2010 was a record year with respect to mean melt extent (Fig. 3b). The simulated minimum mean melt extent was due to a 1972 mean summer (June-August) temperature $\sim 0.7 \pm 0.3^{\circ} \mathrm{C}$ below the $1972-2000$ baseline, and the maximum melt extent was due to a 2010 record high mean temperature $\sim 1.9 \pm 0.6^{\circ} \mathrm{C}$ above the baseline (Fig. 3) in combination with the lower than average winter precipitation. For 2010, the simulated mean melt extent was $28 \%$ $\left(\sim 5.2 \times 10^{5} \mathrm{~km}^{2}\right)$ of the total ice-sheet area and the satelliteobserved melt extent was $23 \%\left(\sim 4.2 \times 10^{5} \mathrm{~km}^{2}\right)$.

The interannual variability in simulated GrIS mean melt extent occurred simultaneously with observed variations in Greenland mean summer air temperatures (at a level of $r^{2}=0.65, p<0.05, r m s e=14 \%$ ) (Fig. 3c). In Figure 3e, time series of seasonal simulated and observed melt extent are shown for 2007 and 2010 (the previous and present record melting years). The variability in seasonal simulated and observed melt extent was very similar. However, by the end of the season in mid-August, the simulations for both years relative to the observations are overestimated by an average of $11 \pm 5 \%$ of the GrlS area. The average seasonal cycle for 1960-2010 indicated that melt extent in the extreme years 2007 and 2010 was about one to two standard deviations greater than average, and that 1972 (the year with minimum melt extent) was one to two standard deviations lower than average (Fig. 4a).

The trend in seasonal melt extent for the simulation period is shown in Figure 4b. From 1960 to 1972 the melting period (with a $>10 \%$ melt extent) decreased by an average of 3 days $^{-1}$. After 1972 the period of $>10 \%$ melt extent increased by an average of 2 days $\mathrm{a}^{-1}$, culminating in an extended melting period of $\sim 70$ days: 40 days in spring and 30 days in spring and autumn (Fig. 4b). Not only did the melting period increase for the GrIS, but also the number of days with a maximum melt extent greater than $30 \%$. The number of days with a melt extent greater than 30\% increased from $\sim 25$ days in 1972 to $\sim 80$ days in 2010, indicating an increasing melt index for the GrIS, where the melt index is defined as the melting area times the number of melting days (Tedesco, 2007). 


\section{CONCLUSION}

Our findings show that GrIS melt extent reveals unambiguously that the melt period decreased from 1960 to 1972 (before satellite observations were available) and increased thereafter at a rate of 2 days $\mathrm{a}^{-1}$, giving an extended melting period of 70 days, beginning 40 days earlier in spring and ending 30 days later in autumn. This increased melt period included record melt extent in 2010 and abnormally long melt duration, 41-60 days greater than average (19602010) at the southwestern and western margin of the ice sheet, supporting the hypothesis that 2010 was an unusually warm and dry year. Simulations of the GrlS melt extent, such as those presented here, will be crucial for understanding $\mathrm{SMB}$, including runoff conditions, since surface meltwater runoff represents about half of the annual mass loss from the GrIS (Zwally and Giovinetto, 2001; Rignot and Kanagaratnam, 2006), with iceberg calving generating most of the other half.

\section{ACKNOWLEDGEMENTS}

We thank J.E. Box and two anonymous reviewers for insightful critiques of this paper. This work was supported by grants from the Climate Change Prediction Program and the Scientific Discovery for Advanced Computing (SciDAC) program within the US Department of Energy's Office of Science, the Los Alamos National Laboratory (LANL) Director's Fellowship, LANL Institute for Geophysics and Planetary Physics, and NASA grant No. NNX08AP34A. LANL is operated under the auspices of the National Nuclear Security Administration of the US Department of Energy under contract No. DE-AC52-06NA25396. We thank the Program for Monitoring of the Greenland Ice Sheet (PROMICE; http://www.promice.org), the Geological Survey of Denmark and Greenland, the Danish Meteorological Institute, the University of Utrecht, the Greenland Climate Network, the University of Colorado at Boulder (http:// cires.colorado.edu/science/groups/steffen/gcnet/) and the Department of Geography and Geology, University of Copenhagen, for providing meteorological data for this study.

\section{REFERENCES}

Abdalati, W. and K. Steffen. 1997. The apparent effects of the Mt Pinatubo eruption on the Greenland ice-sheet melt extent. Geophys. Res. Lett., 24(14), 1795-1797.

Anderson, M.R., T. Mote and W. Abdalati. 1996. A comparison of passive microwave techniques for detecting snowpack melt on the Greenland ice sheet. In Colbeck, S.C., ed. Glaciers, ice sheets and volcanoes: a tribute to Mark F. Meier. Hanover, NH, Cold Regions Research and Engineering Laboratory, 5-9. (CRREL Special Report 96-27.)

Bamber, J.L., S. Ekholm and W.B. Krabill. 2001. A new, highresolution digital elevation model of Greenland fully validated with airborne laser altimeter data. J. Geophys. Res., 106(B4), 6733-6745.

Barnes, S.L. 1964. A technique for maximizing details in numerical weather map analysis. J. Appl. Meteorol., 3(4), 396-409.

Barnes, S.L. 1973. Mesoscale objective map analysis using weighted time-series observations. NOAA Tech. Mem. ERL NSSL-62.

Box, J.E. and 8 others. 2006. Greenland ice sheet surface mass balance variability $(1988-2004)$ from calibrated polar MM5 output. J. Climate, 19(12), 2783-2800.
Chylek, P., C.K. Folland, G. Lesins and M.K. Dubey. 2010. Twentieth century bipolar seesaw of the Arctic and Antarctic surface air temperatures. Geophys. Res. Lett., 37(8), L08703. (10.1029/2010GL042793.)

Douville, H., J.F. Royer and J.F. Mahfouf. 1995. A new snow parameterization for the Météo-France climate model. Part 1. Validation in stand-alone experiments. Climate Dyn., 12(1), $21-35$.

Fettweis, X., M. Tedesco, M. van den Broeke and J. Ettema. 2010. Melting trends over the Greenland ice sheet (1958-2009) from spaceborne microwave data and regional climate models. Cryos. Discuss., 4(4), 2433-2473.

Fettweis, X., M. Tedesco, M. van den Broeke and J. Ettema. 2011. Melting trends over the Greenland ice sheet (1958-2009) from spaceborne microwave data and regonal climate models. Cryosphere, 5(20), 359-375.

Hanna, E., P. Huybrechts, I. Janssens, J. Cappelen, K. Steffen and A. Stephens. 2005. Runoff and mass balance of the Greenland ice sheet: 1958-2003. J. Geophys. Res., 110(D13), D13108. (10.1029/2004JD005641.)

Hanna, E. and 8 others. 2008. Increased runoff from melt from the Greenland Ice Sheet: a response to global warming. J. Climate, 21(2), 331-341.

Koch, S.E., M. desJardins and P.J. Kocin. 1983. An interactive Barnes objective map analysis scheme for use with satellite and conventional data. J. Climate Appl. Meteorol., 22(9), 1487-1503.

Liston, G.E. and K. Elder. 2006a. A distributed snow-evolution modeling system (SnowModel). J. Hydromet., 7(6), 1259-1276.

Liston, G.E. and K. Elder. 2006b. A meteorological distribution system for high-resolution terrestrial modeling (MicroMet). J. Hydromet., 7(2), 217-234.

Liston, G.E. and C.A. Hiemstra. 2008. A simple data assimilation system for complex snow distributions (SnowAssim). J. Hydromet., 9(5), 989-1004.

Liston, G.E. and C.A. Hiemstra. In press. The changing cryosphere: pan-Arctic snow trends (1979-2009). J. Climate.

Liston, G.E., R.B. Haehnel, M. Sturm, C.A. Hiemstra, S. Berezovskaya and R.D. Tabler. 2007. Simulating complex snow distributions in windy environments using SnowTran-3D. J. Glaciol., 53(181), 241-256.

Mernild, S.H. and B. Hasholt. 2009. Observed runoff, jökulhlaups and suspended sediment load from the Greenland ice sheet at Kangerlussuaq, West Greenland, 2007 and 2008. J. Glaciol., 55(193), 855-858

Mernild, S.H. and G.E. Liston. 2010. The influence of air temperature inversions on snow melt and glacier surface mass-balance simulations, Ammassalik Island, Southeast Greenland. J. Appl. Meteorol. Climatol., 49(1), 47-67. (10.1175/2009JAMC2065.1.)

Mernild, S.H., G.E. Liston, B. Hasholt and N.T. Knudsen. 2006. Snow distribution and melt modeling for Mittivakkat Glacier, Ammassalik Island, Southeast Greenland. J. Hydromet., 7(4), 808-824.

Mernild, S.H., G.E. Liston, C.A. Hiemstra and K. Steffen. 2008. Surface melt area and water balance modeling on the Greenland ice sheet 1995-2005. J. Hydromet., 9(6), 1191-1211.

Mernild, S.H., G.E. Liston, C.A. Hiemstra, K. Steffen, E. Hanna and J.H. Christensen. 2009. Greenland ice sheet surface massbalance modelling and freshwater flux for 2007, and in a 19952007 perspective. Hydrol. Process., 23(17), 2470-2484.

Mernild, S.H., G.E. Liston, C.A. Hiemstra and J.H. Christensen. 2010. Greenland Ice Sheet surface mass-balance modeling in a 131-year perspective 1950-2080. J. Hydromet., 11(1), $3-25$.

Mernild, S.H., G.E. Liston, C.A. Hiemstra, J.H. Christensen, M. Stendem and B. Hasholt. 2011. Surface mass-balance and runoff modeling using HIRHAM4 RCM at Kangerlussuaq, (Søndre Strømfjord), West Greenland, 1950-2080. J. Climate, 24(3), 609-623. 
Mote, T.L. 2007. Greenland surface melt trends 1973-2007: evidence of a large increase in 2007. Geophys. Res. Lett., 34(22), L22507. (10.1029/2007GL031976.)

Mote, T.L. and M.R. Anderson. 1995. Variations in snowpack melt on the Greenland ice sheet based on passive-microwave measurements. J. Glaciol., 41(137), 51-60.

Nick, F.M., A. Vieli, I.M. Howat and I. Joughin. 2009. Large-scale changes in Greenland outlet glacier dynamics triggered at the terminus. Nature Geosci., 2(2), 110-114.

Oke, T.R. 1987. Boundary layer climates. Second edition. London, Methuen.

Rignot, E. and P. Kanagaratnam. 2006. Changes in the velocity structure of the Greenland Ice Sheet. Science, 311(5673), 986-990.

Solomon, S. and 7 others, eds. 2007. Climate change 2007: the physical science basis. Contribution of Working Group I to the Fourth Assessment Report of the Intergovernmental Panel on Climate Change. Cambridge, etc., Cambridge University Press.
Steffen, K. 1995. Surface energy exchange at the equilibrium line on the Greenland ice sheet during onset of melt. Ann. Glaciol., 21, 13-18.

Steffen, K. and 6 others. 2008. Rapid changes in glaciers and ice sheets and their impacts on sea level. In Abrupt climate change. Reston, VA, US Geological Survey, 29-66. (US Climate Change Science Program: Synthesis and Assessment Product 3.4.)

Stiles, W.H. and F.T. Ulaby. 1980. The active and passive microwave response to snow parameters. 1. Wetness J. Geophys. Res., 85(C2), 1037-1044.

Tedesco, M. 2007. A new record in 2007 for melting in Greenland. EOS, 88(39), 383.

Tedesco, M. and 7 others. 2011. The role of albedo and accumulation in the 2010 melting record in Greenland. Environ. Res. Lett., 6, 014005. (10.1088/1748-9326/6/1/014005.)

Zwally, H.J. and M.B. Giovinetto. 2001. Balance mass flux and ice velocity across the equilibrium line in drainage systems of Greenland. J. Geophys. Res., 106(D24), 33,717-33,728. 